A $\mathrm{\text {publications }}$ G Rec. Nat. Prod. 14:6(2020) 421-426

records of natural

products

\title{
A New Diarylbenzophenone from Selaginella tamariscina
} Wanling Chen $\oplus^{1 \#}$, Yujie Peng $\odot^{1 \#, ~ W a n x i a ~ H u a n g ~} \oplus^{1}$, Lu Zhou $\odot^{1}$, Xinyu Quan $\odot^{1}$, Qiong Zhao $\oplus^{1}$, Dan Zhang $\oplus^{1}$, Xifeng Sheng $\odot$ ', Yixiao Luo ${ }^{1 *}$ and Hui Zou $\oplus^{1,2 *}$

${ }^{1}$ Key Laboratory of Study and Discovery of Small Targeted Molecules of Hunan Province, School of Medicine, Hunan Normal University, Changsha 410013, R. P. China

${ }^{2}$ Key Laboratory of Epigenetics and Oncology, Research Center for Preclinical Medicine, Southwest Medical University, Luzhou, Sichuan 646000, R. P. China

(Received March 18, 2020; Revised April 27, 2020; Accepted April 29, 2020)

\begin{abstract}
A new diarylbenzophenone, namely selagibenzophenone C (1), along with 1,3-di-p-hydroxyphenyl4-penten-1-one, (2) and unciflavone E (3) were isolated from Selaginella tamariscina. Their structures were elucidated on the basis of spectroscopic and mass spectrometric analyses, including 1D-, 2D-NMR and HRESIMS. Compound $\mathbf{1}$ represents the first example of naturally occurring diarylbenzophenone. Compound $\mathbf{2}$ was firstly isolated from the genus of Selaginella.
\end{abstract}

Keywords: Selaginella; Selaginella tamariscina; diarylbenzophenone; selagibenzophenone C; norlignan. (c) 2020 ACG Publications. All rights reserved.

\section{Plant Source}

The whole herbs of Selaginella tamariscina was collected from ShaoYang City, Hunan Province, R. P. China, on September, 2012 and identified by Prof. Jin-Ping Li (XiangYa School of Pharmaceutical Sciences, Central South University, China). The voucher specimen (JB-005) was deposited in Laboratory of Phytochemistry, School of Medicine, Hunan Normal University.

\section{Previous Studies}

Selaginella tamariscina, a species of selaginella, was included in the 2015 edition of Chinese pharmacopoeia [1], which has been used a traditional herb for the treatment of thrombocytopenic purpura, chronic hepatitis, hyperglycemia, amenorrhea, metrorrhagia and inflammation [2].

\footnotetext{
\# These authors contributed equally to this work.

* Corresponding authors: Email: luoyx@ hunnu.edu.cn (Yixiao Luo) and zouhui308@163.com (Hui Zou)
} 
Pharmacological studies showed it exhibited good bioactivity such as anti-cancer [3-5], antiinflammatory effect [6,7], inhibitory effects on PTP1B enzyme [8,9] and acts as a potent inhibitor to phosphodiesterase-4 (PDE4) [10]. The phytochemical researches revealed flavonoids [7,9], lignans [11], and selaginellins [12,13] as the main chemical constituents of S. tamariscina.

\section{Present Study}

The air-dried S. tamariscina $(30 \mathrm{~kg})$ was extracted with $70 \% \mathrm{EtOH}(10 \mathrm{~L} \times 2 \mathrm{~h} \times 2$ times). The extract was concentrated to $5 \mathrm{~L}$ and suspended in $\mathrm{H}_{2} \mathrm{O}(5 \mathrm{~L})$ and partitioned successively with petroleum ether, EtOAc and $\mathrm{n}-\mathrm{BuOH}$. The $\mathrm{n}-\mathrm{BuOH}$ extract was subjected to a macroporous resin (HPD-100) column with EtOH- $\mathrm{H}_{2} \mathrm{O}$ gradient elution $(30 \%, 50 \%, 70 \%, 95 \%)$ to obtain 4 fractions (AD). The 50\% portion (B) was subjected to a silica gel column (200-300 mesh) eluted with $\mathrm{CH}_{2} \mathrm{Cl}_{2} / \mathrm{MeOH}$ (from 100:0 to 0:100, V/V) to obtain sixty fractions (Fr. B1-B60). Fr.B12-B15 was further separated via ODS silica gel column eluted with $\mathrm{MeOH}-\mathrm{H}_{2} \mathrm{O}(60 \%, 70 \%, 80 \%, 90 \%, 100 \%)$ to provide 92 subfractions (S-Fr. 1-95). The S-Fr. 80 was purified with semi-Preparative HPLC to give 2. The fractions of B26-B32 was separated by ODS silica gel column with gradient elution of $\mathrm{MeOH}-\mathrm{H}_{2} \mathrm{O}(60 \%, 70 \%, 80 \%, 90 \%, 100 \%)$ to provide 90 subfractions (S-Fr. 1-140). The S-Fr. 31 was further purified with semi-preparative HPLC to obatain 3. The S-Fr. 72-73 was further purified with semi-Preparative HPLC to obatain 1 (Figure 1).

Selagibenzophenone $C(\mathbf{1})$ : Red powder. ${ }^{1} \mathrm{H}-\mathrm{NMR}$ and ${ }^{13} \mathrm{C}-\mathrm{NMR}\left(\mathrm{CD}_{3} \mathrm{OD}\right)$ see Table 1 ; HR-ESIMS calcd for $\mathrm{C}_{25} \mathrm{H}_{19} \mathrm{O}_{4}[\mathrm{M}+\mathrm{H}]^{+} \mathrm{m} / z: 383.1286$; found $m / z: 383.1283$.

1,3-Di-p-hydroxyphenyl-4-penten-1-one (2): White powder. ${ }^{1} \mathrm{H}-\mathrm{NMR}\left(\mathrm{CD}_{3} \mathrm{OD}, 400 \mathrm{MHz}\right) \delta_{\mathrm{H}}$ $3.30(2 \mathrm{H}, \mathrm{m}, \mathrm{H}-2), 3.93(1 \mathrm{H}, \mathrm{dd}, J=7.2,15.2 \mathrm{~Hz}, \mathrm{H}-3), 6.02(1 \mathrm{H}, \mathrm{m}, \mathrm{H}-4), 4.98(2 \mathrm{H}, \mathrm{m}, \mathrm{H}-5), 7.86$ $\left(2 \mathrm{H}, \mathrm{d}, J=8.4 \mathrm{~Hz}, \mathrm{H}-2^{\prime}, 6^{\prime}\right), 6.83\left(2 \mathrm{H}, \mathrm{d}, J=8.4 \mathrm{~Hz}, \mathrm{H}-3^{\prime}, 5^{\prime}\right), 7.06\left(2 \mathrm{H}, \mathrm{d}, J=8.5 \mathrm{~Hz}, \mathrm{H}-2^{\prime \prime}, 6^{\prime \prime}\right), 6.71$ $\left(2 \mathrm{H}, \mathrm{d}, J=8.5 \mathrm{~Hz}, \mathrm{H}-3^{\prime \prime}, 5^{\prime \prime}\right) ;{ }^{13} \mathrm{C}-\mathrm{NMR}\left(\mathrm{CD}_{3} \mathrm{OD}, 100 \mathrm{MHz}\right) \delta_{\mathrm{C}} 199.9(\mathrm{C}-1), 44.7(\mathrm{C}-2), 46.1(\mathrm{C}-3)$, 142.9 (C-4), $114.2(\mathrm{C}-5), 130.3\left(\mathrm{C}-1^{\prime}\right), 130.5\left(\mathrm{C}-2^{\prime}, 6^{\prime}\right), 116.2\left(\mathrm{C}-3^{\prime}, 5^{\prime}\right), 163.8\left(\mathrm{C}-4^{\prime}\right), 135.2\left(\mathrm{C}-1^{\prime \prime}\right)$, 129.7 (C-2",6"), 116.2 (C-3",C-5"), 156.8 (C-4").

Unciflavone $E(3)$ : Yellow powder. ${ }^{1} \mathrm{H}-\mathrm{NMR}$ (DMSO- $\left.d_{6}, 400 \mathrm{MHz}\right) \delta_{\mathrm{H}} 6.76(1 \mathrm{H}, \mathrm{s}, \mathrm{H}-3), 6.24$ $(1 \mathrm{H}, \mathrm{s}, \mathrm{H}-6), 7.60\left(2 \mathrm{H}, \mathrm{d}, J=8.4 \mathrm{~Hz}, \mathrm{H}-2^{\prime}, 6^{\prime}\right), 6.75\left(2 \mathrm{H}, \mathrm{d}, J=8.4 \mathrm{~Hz}, \mathrm{H}-3^{\prime}, 5^{\prime}\right), 6.98(1 \mathrm{H}, \mathrm{d}, J=8.4 \mathrm{~Hz}$, $\left.\mathrm{H}-3^{\prime \prime}\right), 7.87\left(1 \mathrm{H}, \mathrm{dd}, J=2.4,8.4 \mathrm{~Hz}, \mathrm{H}-4^{\prime \prime}\right), 7.96(1 \mathrm{H}, \mathrm{d}, J=2.4 \mathrm{~Hz}), 2.47\left(3 \mathrm{H}, \mathrm{s}, 8^{\prime \prime}-\mathrm{CH}_{3}\right) ;{ }^{13} \mathrm{C}-\mathrm{NMR}$ (DMSO- $\left.d_{6}, 100 \mathrm{MHz}\right) \delta_{\mathrm{C}} 163.5$ (C-2), 102.8 (C-3), 182.2 (C-4), 160.8 (C-5), $100.2(\mathrm{C}-6), 165.9$ (C-7), 105.6 (C-8), 154.9 (C-9), 103.2 (C-10), $120.8\left(\mathrm{C}^{\prime} 1^{\prime}\right), 128.6\left(\mathrm{C}-2^{\prime}, 6^{\prime}\right), 116.1\left(\mathrm{C}-3^{\prime}, 5^{\prime}\right), 161.3\left(\mathrm{C}-4^{\prime}\right)$, 120.7 (C-1"), 162.6 (C-2"), 116.1 (C-3"), 130.1 (C-4"), 129.8 (C-5"), 134.2 (C-6"), 196.4 (C-7"), 26.7 $\left(\mathrm{C}-8^{\prime \prime}\right)$.

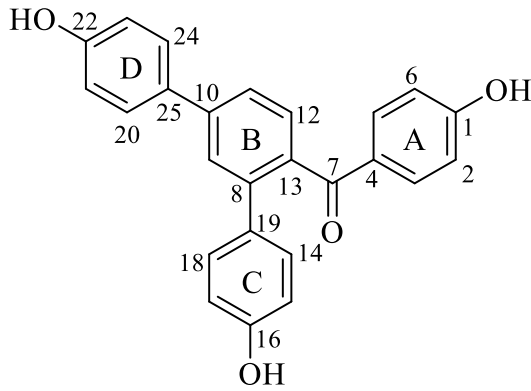

1<smiles>C=CC(CC(=O)c1ccc(O)cc1)c1ccc(O)cc1</smiles>

2

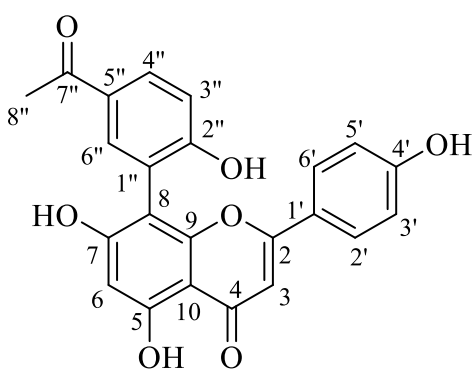

3

Figure 1. Structures of compounds 1-3

Compound 1 was obtained as red powder, which showed an ion peak at $m / z 383.1286[\mathrm{M}+\mathrm{H}]^{+}$ in HR-ESI-MS indicating its molecular formula of $\mathrm{C}_{25} \mathrm{H}_{18} \mathrm{O}_{4}$ (calcd. for $\mathrm{C}_{25} \mathrm{H}_{19} \mathrm{O}_{4}$ : 383.1283), 
indicating 17 degrees of unsaturation. The ${ }^{1} \mathrm{H}$ NMR spectrum of 1 displayed the NMR features for a $1,2,4$-tri-substituted benzene ring $\left[\delta_{\mathrm{H}} 7.62(1 \mathrm{H}, \mathrm{d}, J=1.8 \mathrm{~Hz}), 7.64(1 \mathrm{H}, \mathrm{dd}, J=7.8,1.8 \mathrm{~Hz}), 7.45(1 \mathrm{H}\right.$, $\mathrm{d}, J=7.8 \mathrm{~Hz}$ )] which was confirmed by the correlations between $\mathrm{H}-11$ and $\mathrm{H}-12$ in the COSY spectrum, three para-substituted benzene rings as $\mathrm{AA}^{\prime} \mathrm{BB}^{\prime}$ coupling system corresponding to twelve methines which was also confirmed by HSQC spectrum. Except for 16 degrees of unsaturation for the four benzene rings, the structure of 1 still remains one degree of unsaturation. The ${ }^{13} \mathrm{C}$ NMR spectrum displayed the presence of twenty-four aromatic carbons consisting of six carbon signals for the 1,2,4tri-substituted benzene ring and eighteen carbon signals for three para-substituted benzene rings, and one ketone carbon signal corresponding to one degree of unsaturation.

The HMBC spectrum of 1 showed (Figure 2) correlations from $\delta_{\mathrm{H}} 7.55[\mathrm{H}-\mathrm{C}(3,5)]$ to $\delta_{\mathrm{C}} 163.9$ $(\mathrm{C}-1)$, from $\delta_{\mathrm{H}} 7.14[\mathrm{H}-\mathrm{C}(14,18)]$ to $\delta_{\mathrm{C}} 158.0(\mathrm{C}-16)$, and from $\delta_{\mathrm{H}} 6.59[\mathrm{H}-\mathrm{C}(20,24)]$ to $\delta_{\mathrm{C}} 158.8(\mathrm{C}-22)$ suggested that the three para-substituted benzene rings (rings $\mathrm{A}, \mathrm{C}$ and $\mathrm{D}$ ) are $p$-hydroxyphenyl. The HMBC correlations from $\delta_{\mathrm{H}} 7.55[\mathrm{H}-\mathrm{C}(3,5)], 7.45[\mathrm{H}-\mathrm{C}(12)]$ to $\delta_{\mathrm{C}} 200.2(\mathrm{C}-7)$, from $\delta_{\mathrm{H}} 6.70[\mathrm{H}-$ $\mathrm{C}(2,6)]$ to $\delta_{\mathrm{C}} 130.3(\mathrm{C}-4)$, and from $\delta_{\mathrm{H}} 7.62[\mathrm{H}-\mathrm{C}(9)], 7.64[\mathrm{H}-\mathrm{C}(11)]$ to $\delta_{\mathrm{C}} 138.3(\mathrm{C}-13)$ indicated rings $\mathrm{A}$ and $\mathrm{B}$ established a mother nucleus structure of benzophenone. The HMBC corelations from $\delta_{\mathrm{H}} 7.62[\mathrm{H}-\mathrm{C}(9)], 6.67[\mathrm{H}-\mathrm{C}(15,17)]$ to $\delta_{\mathrm{C}} 133.1(\mathrm{C}-19)$, and from $\delta_{\mathrm{H}} 7.14$ [H-C(14,18)], 7.45 [H-C(12)] to $\delta_{\mathrm{C}} 142.6(\mathrm{C}-8)$, suggested that ring $\mathrm{C}$ was linked to the $\mathrm{C}-8$ of ring $\mathrm{B}$. Furthermore, the HMBC correlations from $\delta_{\mathrm{H}} 7.62[\mathrm{H}-\mathrm{C}(9)], 7.64[\mathrm{H}-\mathrm{C}(11)]$ and $6.92[\mathrm{H}-\mathrm{C}(21,23)]$ to $\delta_{\mathrm{C}} 132.6(\mathrm{C}-25)$, and from $\delta_{\mathrm{H}} 6.59[\mathrm{H}-\mathrm{C}(20,24)], 7.45[\mathrm{H}-\mathrm{C}(12)]$ to $\delta_{\mathrm{C}} 144.3(\mathrm{C}-10)$, suggested ring D was linked to the C10 of ring B. Thus, compound 1 was elucidated as (4,4"-dihydroxy-[1,1':3',1"-terphenyl]-4'-yl)(4hydroxyphenyl)methanone, a new diarylbenzophenone named as selagibenzophenone $\mathrm{C}$. To the best of our knowledge, compound $\mathbf{1}$ is the first example of diarylbenzophenone as natural sources.

Table 1. ${ }^{1} \mathrm{H}$ NMR $(400 \mathrm{MHz})$ and ${ }^{13} \mathrm{C}$ NMR $(100 \mathrm{MHz})$ data for 1 in $\mathrm{CD}_{3} \mathrm{OD}(\delta$ in ppm)

\begin{tabular}{ccc}
\hline No. & $\delta_{\mathrm{C}}{ }^{\mathrm{a}}$ & $\delta_{\mathrm{H}}($ mult., $J$ in Hz$)$ \\
\hline 1 & $163.9, \mathrm{C}$ & $6.70(1 \mathrm{H}, \mathrm{d}, J=8.4 \mathrm{~Hz})$ \\
2,6 & $116.0, \mathrm{CH}$ & $7.55(1 \mathrm{H}, \mathrm{d}, J=8.4 \mathrm{~Hz})$ \\
3,5 & $133.8, \mathrm{CH}$ & \\
4 & $130.3, \mathrm{C}$ & \\
7 & $200.2, \mathrm{C}$ & $7.62(1 \mathrm{H}, \mathrm{d}, J=1.8 \mathrm{~Hz})$ \\
8 & $142.6, \mathrm{C}$ & \\
9 & $128.7, \mathrm{CH}$ & $7.64(1 \mathrm{H}, \mathrm{dd}, J=7.8,1.8 \mathrm{~Hz})$ \\
10 & $144.3, \mathrm{C}$ & $7.45(1 \mathrm{H}, \mathrm{d}, J=7.8 \mathrm{~Hz})$ \\
11 & $125.4, \mathrm{CH}$ & $7.14(2 \mathrm{H}, \mathrm{d}, J=8.4 \mathrm{~Hz})$ \\
12 & $130.1, \mathrm{CH}$ & $6.67(2 \mathrm{H}, \mathrm{d}, J=8.4 \mathrm{~Hz})$ \\
13 & $138.3, \mathrm{C}$ & \\
14,18 & $131.2, \mathrm{CH}$ & \\
15,17 & $116.1, \mathrm{CH}$ & $6.59(2 \mathrm{H}, \mathrm{d}, J=8.4 \mathrm{~Hz})$ \\
16 & $158.0, \mathrm{C}$ & $6.92(2 \mathrm{H}, \mathrm{d}, J=8.4 \mathrm{~Hz})$ \\
19 & $133.1, \mathrm{C}$ & \\
20,24 & $129.3, \mathrm{CH}$ & \\
21,23 & $116.8, \mathrm{CH}$ & \\
22 & $158.8, \mathrm{C}$ &
\end{tabular}




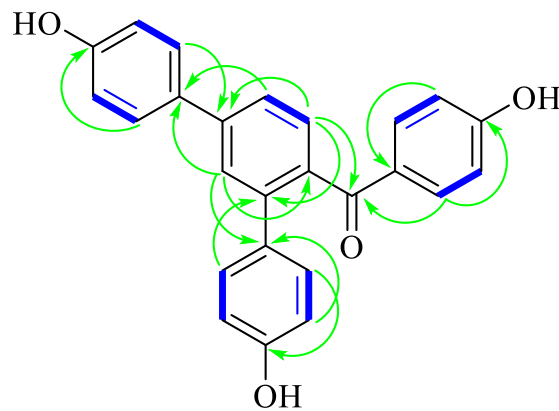

Figure 2. Key ${ }^{1} \mathrm{H}_{-}{ }^{1} \mathrm{H} \mathrm{COSY}(-)$ and $\mathrm{HMBC}(\longrightarrow)$ correlations for compound $\mathbf{1}$

The two known compounds were identified as 1,3-di-p-hydroxyphenyl-4-penten-1-one (2) [14] and unciflavone E (3) [15] by comparing their NMR data with those reported in the literature. Compound $\mathbf{2}$ is a norlignan which was firstly isolated from this genus.

In the genus of Selaginella, two species (S. tamariscina and S. pulvinata) attracted more attention for its pharmacologic action and structural diversity of secondary metabolites. In Chinese, these two species are often replaced by each other. Many studies revealed that they have a lot of the same structure types of their chemical constituents. In previous studies, the first natural source of triarylbenzophenone was isolated from S. pulvinata [16], following that we reported the second one from S. tamariscina [17]. We carry out a continued study on the bioactive secondary metabolite of $S$. tamariscina, and the first naturally occurring diarylbenzophenone was found in our present study. Our study added new structure type to this plant. Maybe more of such compounds will be isolated from Selaginella.

The natural products with basic structure of benzophenone were isolated from many plants and exhibited cytotoxic and antibacterial activity [18-20]. In terms of biosynthetic pathway, we suspected that diarylbenzophenones and triarylbenzophenones are synthesis via the cross-coupling reactions base on the benzophenone. Nawaz MA., et al [21] reported a synthetic method of diarylbenzophenones based on site-selective suzuki cross-coupling reaction. Khera R.A., et al. [22] reported the suzuki and sonogashira cross-coupling reactions to synthesize diarylbenzophenones.

\section{Acknowledgments}

This studies was supported by Scientific research project of changsha science and technology bureau (kq1907131), Outstanding youth project of education department of hunan province (19B363 and 15B142), Innovative experiment program for college students, Opening Fund of Key Laboratory of Chemical Biology and Traditional Chinese Medicine Research (Hunan Normal University), Ministry of Education (KLCBTCMR18-06), and the Joint Research Fund of QiLu Pharmacuetical Co. Ltd.

\section{Supporting Information}

Supporting Information accompanies this paper on http://www.acgpubs.org/journal/recordsof-natural-products

\section{ORCID}

Wanling Chen: 0000-0003-3675-8991

Yujie Peng: 0000-0002-9822-6694

Wanxia Huang: 0000-0001-8169-3950

Lu Zhou: 0000-0003-0578-760X

Xinyu Quan: 0000-0002-2022-5712

Qiong Zhao: 0000-0002-5348-6935 
Dan Zhang: 0000-0001-8004-3817

Xifeng Sheng: 0000-0002-2899-994X

Yixiao Luo: 0000-0001-5013-1998

Hui Zou: 0000-0003-4594-6302

\section{References}

[1] Chinese Pharmacopoeia Commission, Chinese Pharmacopoeia, (China Medical Science Press, Beijing, China, 2015), 1, 226.

[2] P. H. Nguyen, B. T. Zhao, M. Y. Ali, J. S. Choi, D. Y. Rhyu, B. S. Min and M. H. Woo (2015). Insulinmimetic selaginellins from Selaginella tamariscina with protein tyrosine phosphatase 1B (PTP1B) inhibitory activity, J. Nat. Prod. 78, 34-42.

[3] C. G. Wang, W. N. Yao, B. Zhang, J. Hua, D. Liang and H. S. Wang (2018). Lung cancer and matrix metalloproteinases inhibitors of polyphenols from Selaginella tamariscina with suppression activity of migration, Bioorg. Med. Chem. Lett. 28, 2413-2417.

[4] H J. Park and M. M. Kim (2019). Amentoflavone induces autophagy and modulates p53, Cell J. 21, 27 34.

[5] B. Liu and S. Yu (2018). Amentoflavone suppresses hepatocellular carcinoma by repressing hexokinase 2 expression through inhibiting JAK2/STAT3 signaling, Biomed. Pharmacother. 107, 243-253.

[6] A. N. Won, S. A. Kim, J. Y. Ahn, J. H. Han, C. H. Kim, J. H. Lee and D. I. Kim (2018). HO-1 Induction by Selaginella tamariscina extract inhibits inflammatory response in lipopolysaccharide-stimulated RAW 264.7 Macrophages, Evid. Based. Complement. Alternat Med. 2018, 7816923.

[7] S. Y. Shim, S. G. Lee and M. Lee (2018). Biflavonoids isolated from Selaginella tamariscina and their anti-inflammatory activities via ERK 1/2 signaling, Molecules 23, 926.(12 pages).

[8] D. D. Le, D. H. Nguyen, B.T. Zhao, S. H. Seong, J. S. Choi, S. K. Kim, J. A. Kim, B. S. Min and M. H. Woo (2017). PTP1B inhibitors from Selaginella tamariscina (Beauv.) spring and their kinetic properties and molecular docking simulation, Bioorg. Chem. 72, 273-281.

[9] P. H. Nguyen, D. J. Ji, Y. R. Han, J. S. Choi, D. Y. Rhyu, B. S. Min and M. H. Woo (2015). Selaginellin and biflavonoids as protein tyrosine phosphatase 1B inhibitors from Selaginella tamariscina and their glucose uptake stimulatory effects, Bioorg. Med. Chem. 23, 3730-3737.

[10] S. Woo K. B. Kang, J. Kim and S. H. Sung (2019). Molecular networking reveals the chemical diversity of selaginellin derivatives, natural phosphodiesterase-4 inhibitors from Selaginella tamariscina, J. Nat. Prod. 82, 1820-1830.

[11] L. D. Dat, B. T. Zhao, N. D. Hung, J. H. Lee, B. S. Min and M. H. Woo (2017). Lignan derivatives from Selaginella tamariscina and their nitric oxide inhibitory effects in LPS-stimulated RAW 264.7 cells, Bioorg. Med. Chem. Lett. 27, 524-529.

[12] J. K. Heo, P. H. Nguyen, W. C. Kim, N. M. Phuc and K. H. Liu (2017). Inhibitory effect of selaginellins from Selaginella tamariscina (Beauv.) spring against cytochrome P450 and uridine 5'diphosphoglucuronosyltransferase isoforms on human liver microsomes, Molecules, 22, 1590. (8 pages).

[13] C. Yang, Y. Shao, K. Li and W. Xia (2012). Bioactive selaginellins from Selaginella tamariscina (Beauv.) spring, Beilstein J. Org. Chem. 8, 1884-1889.

[14] S. J. Jeong, N. H. Ahn, Y. C. Kim, M. Inagaki, T. Miyamoto and R. Higuchi (1999). Norlignans with hyaluronidase inhibitory activity from Anemarrhena asphodeloides, Planta Med. 65, 367-368.

[15] H. Zou, K. P. Xu, F. S. Li, Z. X. Zou, R. Liu, R. H. Liu, J. Li, L. H. Tan and G. S. Tan (2014) Unciflavones A-F, six novel flavonoids from Selaginella uncinata (Desv.) spring, Fitoterapia 99, 328333.

[16] X. Liu, G. H. Tan, H. Z. Weng, J. S. Zhang, Y. K. Xu and S. Yin (2018). A new selaginellin derivative and a new triarylbenzophenone analog from the whole plant of Selaginella pulvinata, J. Asian. Nat. Prod. Res. 20, 1123-1128.

[17] R. Liu, H. Zou, Z. X. Zou, F. Cheng, X. Yu, P. S. Xu, X. M. Li, D. Li, K. P. Xu and G. S. Tan (2018). Two new anthraquinone derivatives and one new triarylbenzophenone analog from Selaginella tamariscina, Nat. Prod. Res. doi: 10.1080/14786419.2018.1452008.

[18] S. M. Li, J. Qi and J. P. Kou (2012). Research status of natural benzophenones from plants, Prog. Pharm. Sci. 36, 452-458. 
[19] X. Zhu, W. Ouyang, C. Pan, Z. Gao, Y. Han, M. Song, K. Feng, H. Xiao and Y. Cao (2019). Identification of a new benzophenone from Psidium guajava L. leaves and its antineoplastic effects on human colon cancer cells, Food Funct. 10, 4189-4198.

[20] N. Celebioglu, U. Ozgen and H. Secen (2017). Naturally occurring 1,5-Diarylpentanoids: A Review. Org. Commun. 10, 250 - 258

[21] MA. Nawaz, MA. Adeel, M. F. Ibad and P. Langer (2009). Synthesis of functionalized 2',4diarylbenzophenones based on site-selective Suzuki cross-coupling reactions, Synlett 2009, 2154-2156.

[22] R. A. Khera, MA. Nawaz, H. Feist, A. Villinger and P. Langer, (2012). Synthesis of functionalized 3,4diarylbenzophenones and 2,4-diarylbenzophenones by site-selective suzuki and sonogashira crosscoupling reactions of bis(triflates) of 3,4- and 2,4-dihydroxybenzophenone, Synthesis 44, 219-234.

\section{A C G \\ publications \\ (C) 2020 ACG Publications}

